\title{
VI. Observations on pot-ash; being an inquiry how far the mischievous effects of septic acid are restrained by pot-ash and other alkalies, particularly in respect to the effects of septite of pot-ash (nitre or saltpetre) upon animal flesh intended to be eaten, and upon the human stomach; in a Letter from Dr. Mitchill to Dr. Priestley, dated Plandome, May 4, 1799
}

Dr. Sam L. Mitchill

To cite this article: Dr. Sam L. Mitchill (1799) VI. Observations on pot-ash; being an inquiry how far the mischievous effects of septic acid are restrained by pot-ash and other alkalies, particularly in respect to the effects of septite of pot-ash (nitre or saltpetre) upon animal flesh intended to be eaten, and upon the human stomach; in a Letter from Dr. Mitchill to Dr. Priestley, dated Plandome, May 4, 1799, Philosophical Magazine Series 1, 5:18, 146-154, DOI: $10.1080 / 14786449908677131$

To link to this article: http://dx.doi.org/10.1080/14786449908677131 


\section{$\left[\begin{array}{lll}1 & 146 & ]\end{array}\right.$}

VI. Obfervations on Pot-a/b; being an Inquiry borv far the mifckievous Effects of Septic Acid are reflruined by Pot-afk and otber Alkalies, particularly in reffect to the Efeets of Septite of Pot-afh (Nitre or Saltpetre) upon Animal Fleß intended to be eaten, and upon the Human Stomacb; in a Letter from Dr. Mitcibill to Dr. Prieflley, datcd Plandome, May 4, 1799. Communicated by Dr. MrтCHILL.

$\mathrm{N}$ a former occafion (2 Medical Repofitory, p. 236 et jeq.) an attempt was made to flew that the feptic acid, which is formed in certain putrefactive procefes, was materially different in its conflitution and qualities from the nitrous acid obtained by diftillation from faltpetre. Since the compofition of that piece, I have obferved that Juncker, in his view of the doctrines of Beccher and Stahl, (2 Confpectus Chinie, p. 280,) is of the fame opinion, declaring, that in whatever manner the work of feparating it from the putrefeent or other bodies with which it was naturally mingled, was undertaken, " ne micula tamen acidi nitrofi pure fiftitur," not a particle of pure nitrous acid can be obtained. And he warns his reader, that in the obfervations which he offers he rneans that fpirit of nitre ONLY which is liberated from its conncetion with an alkaline falt. On the native feptic acid, which is, as he allows, furnithed fo largely by the aninal kingdom, $(p, 277$, ) and is by far the mott active and interefing form of oxygenated fepton, Juncker, like molt other writers, has faid fearcely any thing at all.

The highly deftructive effeets of this offspring of putrefaction have been pointed out in detail in a former elfay (I Met dical Repofitory, p. 39, 40), in which it was obferved that certain fubftances, and among others pot-afh in particular, poffefled a power to reftrain and curb its ferocity. The neutral falt, formed by the union of this peftilential acid with the fixed alkali, is the faltpetre or nitre of the fhops and of commerce. Concerning the medicinal and economical qualities of this fubftance, it is manifert to me that there are nany miftakes yet prevalent: and they appear to be worthy of being pointed out and corrected. 
The feptite of pot-an has been denominated a falt of many excellent qualities, a fal polycbreflus; and a great phyfician once wifhed, for the good of his profeftion, there could be found one other remedy fo certain and fteady in curing difeafes as nitre. It has likewife been termed an antiphlogiflic remedy, good for all manner of infammatory difeafes with phlogiftic denfity of the blood; poffeffing fine attenuating powers, being in nowife acrimonious; and happily calculated to withltand a putrefcent ftate of the body. It has further been called a refrigerant, a ciuretic, and a carminative, and cmployed accordingly by thofe prefcribers who are infuenced by the nominul efficacy of remedies.

Such are fome of the fuperlative effects afcribed to this compound of the acid of peftilence and pot-ah : and for a confiderable time after I became acquainted with the mifchievous effects, wrought occafionally by the naked feptic acid, I remained in the belief that the ftrongeft of the alkalies coald hold it fart, and kcep it entirely harmlefs. It therefore did not appear to me improbable that the character of the compound of the two might, as in a multitude of other cafes, be exceedingly different from that of either the conftituent acid or alkali.

But latterly I have been inclined to the opinion, that potan is capable of combination with oxygenated fepton in different degrees ; that is to fay, fepton, before combining with the alkali, may have been united to more or lefs of oxygen; and alfo fepton, in any of its degrees of oxygenation, may be united with pot-afh in different proportions: in other words, the acid may vary in its Jirengtb, and likewife, on cvery degree of ftrength, may be united to the alkali in various proportion. The nitrum nitratum, defcribed by the older chemifts, is an example of pot-ahb juper-faturated with nitric acid, and, Atrange to tell! has been extolled for its advanfageous operation in ardent fevers, accompanied with thirft and with a dry and foul tongue. I have ftrong reafon to think that there is a difproportion between the acid and alkali in other forms of nitre; as I have known litmus-paper to be turned repeatedly reddifh by a watery folution of faltpetre, the refidue of a quantity which was fwallowed by 
miftake, and which nearly deprived a man of his life. A fet of correct experiments is wanting to elucidate more completely this part of a very curious and highly important fubject.

Be thefe things as they may, all experience fhews that the connexion between feptic acid and pot-afh is eafy to diffolve; at leaft, a portion of oxygen feparates very readily from the nitre. The experiment of reddening blood by mixing powdered faltpetre with it, was known to Hofman, and, I think, fairly evinces a partial decompofition of the falt. It feems to have a fimilar operation upon the refidue of that fluid in the fleth of flaughtered animals, and the reddening of the lean and fibrous part of meat is evidently owing to the oxygen attracted from the nitre.

But a heightening of colour is not the only effect which feptite of pot-afh works upon provifions fprinkled with it. There are in many meats, elpecially of old animals, and of thofe which have been a long time falted, a tougline/s and bardnefs which render them difficult to be cut and to be chewed. The feptic acid feems in fome degrce to be difjoined from the pot-afh, and evidently affins in decompofing, to a certain point, the vafcular and fibrous ftructure of the meat. The quantity of nitre generally put on is fmall; was the proportion larger, the meat would be yet further diforganifed, and be rendered more foort and tender, almuft even to rottenne/s. But the injurious eflect of the nitre is prevented by the fea-falt commonly mingled with it, in the manner and upon the principle defcribed in my "Obforvations on Soda." (2 Medical Repofitory, p. 292, et feq.) The ufe of faltpetre, then, in curing provifions, is to make them reddif $b$ and tender, and not to exercife an antifeptic and bardening power, as the muriate of foda does.

With all thefe confiderations before me, I entertained great doubts of the truth of thofe fine things told over and again, and copied by one writer from another, about the mildnefs and wholefomenefs of nitre, and of its wonderful effects as a calmer and foother of difeafes. It feemed very Arange to me, that the acid which before its union with pot-ath was capable of caufing fevers, fhould be fo fuddenly transformed, 
kransformed, as, notwithftanding the laxity of their cohefion, to cure fuch difeafes immediately afterwards.

While I was confidering thefe things, a cafe fell under my obfervation, which aliowed me fully to witnefs the operation of this boatted cooler, carminative, and fubrifuge. It hews, beyond a doubt, that feptic acid, though coerced by pot-afh, is in fome degree feptic acid ftill. Its native virulence does not even then wholly forfalse it, Nitre ought to be ranked among the poifons; for, in a fufficient dofe, it is truly a poifon. Though it may be adminiftered in fmall quantities without exciting terrible fymptoms, it refembles in that refpect molt other venomous fubftances, which can be fwallowed without detriment, and even often with advantage, when their dofe is not too large. It is time for writers of Difpenfatories, and on Materia Medica, to know the facts concerning nitre and its operation, and to publifh them for the fake of undeceiving their readers. Too lang has the medical world been the dupe of idle and partial opinions on this fubject. Read the foilowing accident, and judge of what I have faid from the fymptoms induced by fwallowing feptite of potafh or faltpetre:-

A carman, of middle age, had followed his bufinefs as ufual on Saturday the zoth day of April 1 \%99. On Sunday morning he determined to take a faline cathartic for an indifpofition too trifing to require the advice of a phyfician. Accordingly his wife diffolved an ounce of what the believed to be fulphate of foda (Glauber's falt) in water, and gave it to him at a draught. He fwallowed it. Soon after he was feverely incommoded by what he termed " a great weaknefs about his heart." Naufea came on, and was followed by vomiting of the contents of the ftomach, mixed with confiderable quantities of blood at each time. His trength was exceedingly impaired: and a fenfation of coldnefs over the whole body was remarked by him, particularly in the extremities. I did not fee him until after the bloody vomiting had continued at times for feveral hours, and then his pulfes at the writt were very flow. He was however quite rational, and faid he then felt much better than he had done. On examining what kind of falt he had taken, for fome cryftals of it remained in a wide-mouthed bottle, I found it to be fep- 
tite of pot-afh (faltpetre.) This was about eleven o'clock before noon, and he had taken it at fix in the moming. As it had had no purgative effect, $I$ crdered him fome caftor-oil, and almond milk fweetened with fugar, or fome milk-whey, and fome water-gruel.

In 35 Commentar. de Rebus, 8rc. p. 176, a care is men. tioned of death from taking an ounce of nitre: and if a part of the quantity which this man took had not been vomited up, he probably would have died too. The ol, ricini purged him gently, and he gradually got better, but complained very much of weaknefs about the præcordia.

There are numerous other accidents not materially unlike thefe. Such occurrences give us no very favourable account of the benignity of nitre as a medicine. It is a pity that practifers of phyfic do not better underftand the component parts of their preficriptions. How few know that, in adminiftering nitre, their patients are made to fwallow a portion of the naufeating and fickening acid of putrefaction!

Poffibly thefe remarks may have a tendency to remove the doubt contained in your letter of April 11, 1799. You will hereby perceive that my native acid of fepton is a combination of this bafis with oxygen and water; whereas your artificial acid of nitre undergoes a partial decompofition by the heat of diftillation, and is adulterated befides with whatever happens to be mingled with it during and after its combination with the vegetable fixed alkali. And both thefe forms of acid differ from atmofpherical air; inafmuch as the former are cbemical mixtures, the latter is mecbanical.

It would be better for fcience if the word "nitre" was re. jected altogether from ufe. Nitria, whence the term comes, was, you know, a diftrict of ancient Egypt, famous for the quantity of mineral alkali which it afforded. (D'Anville's Geograph.-Egypt.) This faline fubltance has thence been called by the names nitrum, nitre, \&c. In confirmation of which, I obferve, in the Dictionary of Calepinus, printed at Bafil in $153^{8}$, that what they called nitrum was a material employed to cleanfe clothes, and wafh the bodies which wore them. And S. Bochart remarks, (I Opera. Chanan, L. II. cap. xis.) that the ancients made a kind of ley from a/bes, foda, 
foda, and bole, (cinere, nitro, et cimolia,) for more effectually clearing their bodies from naftinefs when they bathed. I need not remark to you, that I employ the word " nitre," not in its ancient, but modern fenfe.

It is highly defirable that fome of our men, whofe opinions have weight with the public, would perufe the work of Lancifi, phyfician to Pope Clement XI, on the noxious exhalations of marthes. (De Nox. Palud. Effluviis.) By the perfevering and luninous refearches of this great man, it was found, as long ago as the year $17 \pm 6$, that marh-water, by fimple difillation, (Ibid. Lib. II. c. xii.) manifefted an acid quality; and that calcareous ftones (Ibid. Lib. II. c. ii.) were better for paving the freets of cities than filiceous ones, becaufe the alkaline nature of the former was adapted to imbibe the noxious moifture of the air, and fweeten the acid falts with which it abounded. Indeed, much of the matter detaled by the writers of our days on local fources of diftempers, may be found better obferved, and better ftated, by Lancifi, than in their writings. By the by I obferve he mentions the Englih philofopher Mayow, (lbid. Lib. II. P. ii. cap. 2.)

If the philofopher of Rome had reafoned upon his own difcovery, he could not have failed to draw the inference, that by alkaline julffances might the HYDRA of peftilence be orercome.-As I have mentioned this monfter, I fhall paufe a little to give you my opinion of the allegory among the ancients concerning her: and $I$ attenpt the explanation the more willingly, as I believe Lord Verulam has faid nothing about it. The fable is this :-In leloponnefus, between Mycenæe and Argos, there was a fen or marth of fome extent called Lerna. This muddy and ftagnating pool was inhabited by Hydra, a homible and devouning monfer with feveral heads; fome fay feven, others nine, and others fifty. The malignity of her poifon was fuch that a mound from an arrow dipped into it was inftantly mortal. She made dreadful havoc among the people of the furrounding country, and devoured a great number of their fheep and other cattle. In obedience to the orders of the tyrant Eurytheus, Hercules went to fight this deftructive and formidable creature. On 


\section{Dr. Mitibill's Obfervations on Pot-Afb,}

his approach, a crab came forth to the affiftance of Hydra . but Hercules crufhed the crab, and afterwards hew Hydra. Of the heads of Hydra, it was reported, when one was cut off, two would fprout from the wound, unlefs prevented by the immediate application of fire. Hercules, availing himfelf of the aid of fire, fucceeded in his undertaking. In the ninth figure of Montfaucon's 66th plate, there is a figure of Hercules with crabs near his feet, having, as the learned father curioufly enough remarks, a relation to fome myftery which he does not comprehend. (I Antiquity explained, Art. Hercules, chap. ix.)

Now, it appears to me, this is an allegory expreffive of the peftilential vapours emitted by the bog of Lerna, and of the means found by experience ufeful to drain off its ftagnant water, and to clear the adjoining and furrounding moraffes.

The word "hydra" is derived from idup, water. This fluid then, detained upon the marfh of Lerna, favouretd oecafionally the production of unwholefome exhalations. Such vapours, being at once invifible and injurious, were afcribed to fome preternatural enemy or deftructive monfter; and being diffufed, or wafted around the country, and oftentimes cutting off both man and bealt, were fancied to be the effect of the fuppcfed monfter's poifon. According to their extent and virulence was the reported to have fewer or more heads for preparing and inflicting this poifon. The mere draining off the water, and leaving the mud and thime bare, was termed cutting off an head; and the increafe of deleterious gafes, in confcquence of expofing fuch a naked furface, was aptly expreffed by the fprouting forth of two in its place. By cauterifing, or fearing, was underftood either the folar heat in drying the ground after the water was drained away, or the burning up of the trees, fhrubs, and obftacles to free ventilation by ordinary combuftion, or perhaps both. The crab, who was Hydra's ally, perhaps does not refer to the fun's place in the conftellation Cancer, fo much as to flew the frequent recurrence of the difficulties, and the fuperior ftrength and fkill requifite to overcome them. In the whole allegory "Hercules" may be underftood to mean "infuperable courrage and induftry." North America, at the clofe of the 18 th 
century, wants a Hercules. This interpretation is confirmed by another confideration, that the ancients had not only their Hydra, who lived in the water, but their Cberfydra, who remained after the marfh or fen was dried up. Cher$\int y d r a$, being derived from the two words, xspoos, land not fit for the plough; and udga, the monfter of the fens; will thus mean the venomous and fickly condition of the neighbouring atmofphere after the water was exhaled, and the ground at the fame time not rendered arable thereby, typified by a poifonous ferpent : and was thus expreffive of the rage of peftilential effluvia, which fometimes, and under certain circumftances, continue in a virulent ftate, in dry weather, near their dried fources.

Hydra is feemingly mentioned by Virgil (En. vi. v. 576.) as a fictitious or poetical animal. Bochart, however, with his ufual prodigious erudition, appears defirous to make the whole ftory terally intelligible. (Hierozoici pars pofter. Lib. III. cap. xiii.) But Lancifi, with a more clear and difcriminating mind, perceives that important phyfical truths are concealed under this two-fold allegory, and hews how they are to be unriddled. (De Nox. Palud. Eff. Lib. II. p. ii. cap. 3.) In confidering thefe matters you will not fail to recollect that the claffical writers, and others, ufe the word "hydrus" as well as "hydra," and fome of them apparently confound the two. The former noun of the mafculine gender is probably the name of the real animal, the water-jnake, the latter of the imaginary one.-But of this enough.

If peftilential matter, as I obferved before, can be fubdued by alkalies, then the formation of feptite of pot-afh in the alimentary canal mult be a very frequent and common procefs. It is univerfally agreed that peftilential matter may be taken into the ftomach by fwallowing; and no reafonabla doubt can be entertained of its production within that organ, and other parts of the inteftinal tube, from the corrupted remains of food. The whole tenor of prefcription, as explained in my letter concerning the ufe of alkaline remedies in fevers, (I Medical Repof. p. 265.) goes to fhew that the offending caufe is of an acid quality: and in its wort forms, I think the acid engendered has fepton for its bafis ; fince aliment, Vor. V. 
containing this principle only, is capable of yielding that matt noxious compound. When feptic acid thus exifts in the alimentary canal, and carbonates, tartrites, \&c. of pot$\mathrm{a} h$, are taken down, the ftronger acid is attracted, and a proportional quantity of nitre or faltpetre is formed. Thus, in abundance of cafes, the practifers who are fond of prefiribing feptite of pat-afh might fpare themfelves the trouble, as that faline compound is, in certain cafes, formed in the ftomach and bowels in confiderable quantity. What precife effect the nitre fo formed has on the inteltines, and on the conftitution at large, deferves to be inquired into with great care; for I am not without apprehenfion that fome of the fad fymptoms, occafionally attendant on fevers, are modified by the feptite of pot-aftr formed within the belly.-I believe, however, I muft now ftop; and trouble you no further for the prefent than by afluring you, that I hope much from your aid in this inquiry, which you inform me you confider " as a happy train of difcovery;" and that I am, very refpectfully, yours,

To Dr. Prieflley.

SAM. L. MITCHILL.

VII. Defcription of a Mercurial Gazometer conftructed by $M r$. W. H. Pepys jun. Communicated by tbo Autbor.

$\mathrm{T}$

HE difficulty attending the exhibition of acid and alkaline gafes, was the firft inducement to Prieftley, Lavoifier, and others, fo ufe mercury for fuch experiments; but the great expence and enormous weight of this fluid obliged many accurate and experienced chemifts to relinquifh them alnoft entirely, as there appeared no other likely means of fueceeding but by its means and that of the exhaufted receiver. A contrivance to leffen the quantity of mercury neceffary for fuch experiments was therefore a defrable objeet; and by introducing the dome ufed by Mr. Watt in his hydraudic bellows, I have fucceeded in eonftrueting an ap. paratus in which both of the above-mentioned requifites are obtained at a comparatively fmall expence. As it is hardly 